\title{
AN ANALYSIS OF MORAL VALUE IN 47 RONIN FILM
}

\author{
Yohanes Johardianto \\ Department of Language and Literature, Kanjuruhan University of Malang \\ Jln. S. Supriadi No. 48 Malang, Jawa Timur 65148, Indonesia \\ Phone : 082337753373 \\ E-mail : yohanesjojodianto2@gmail.com \\ Siane Herawati \\ Department of Language and Literature, Kanjuruhan University of Malang \\ Jln. S. Supriadi No. 48 Malang, Jawa Timur 65148, Indonesia \\ Phone :082141719799_E-mail :siane.herawati@yahoo.com \\ Maria G. Sri Ningsih. \\ Department of Language and Literature, Kanjuruhan University of Malang \\ Jln. S. Supriadi No. 48 Malang, Jawa Timur 65148, Indonesia \\ Phone :085933033177 ～E-mail :m.g.sriningsih@gmail.com
}

\begin{abstract}
We have been quite familiar with art and literary work in our life. They can be music, pain or literature. Literature is human expression consisting experience, consideration, feeling, idea, spirit, and conviction in form of concrete description that arouse attraction by using language. Literature is the result of ideas that belongs to human. The result of literary works can be written work, pictures or music. Literary works in written form include the novel, poem, short story, verse, etc. While in pictures form include painting, movie, photograph, etc. And literary works in the form of music include songs that every day we listen.
\end{abstract}

This thesis is an effort to analyze the moral values in the movie entitled "47 Ronin", which might be very useful for the researcher himself, the readers, and other researchers who might need it as source of information. There are three research problems proposed from this "47 Ronin" analyzing film. They are: (1) The moral value found on this film, (2) The moral values conveyed on this film, (3) The messages that can be delivered to the viewers. Based on the result of this study the researcher found some moral values contained in the movie" 47 Ronin", such as: friendliness, tolerance and acceptance, self-confidence, determination, honesty, positive attitude, patience, initiative and courage, motivation, self respect. The researcher hopes those values would be useful for the Viewers and the readers of this thesis as their life guidance to be better persons.

Keywords: Moral Value, "47 Ronin” Film

\section{Introduction}

Movie is a communication media that gives valuable messages to audiences. Movie has a storyline with interesting words that make this media to be very important in human existence. The chosen language that is used in the movie is not simple words but has made a connection with literary language in one storyline. It produces a unique creation and feasible to be consumed by all audience. Literature is a writing creation that expresses live experience with choosing word and gives dramatic effect in every word. The use of language is connotative; its aim is to make the literary work can be accepted by all audiences. Literature is a media to deliver creative ideas. In movie as a literature 
creation has interesting media to communicate with audiences that the moviegoer can catch the message of the movie. Movie has one message that delivered, and audience must find it. It can be said that movie gives message to audience to get ideas of moviemaker. In addition, the movie has educational messages. Educational messages in the movie have same function as the sender message similar to complexity, because the audience has to interpret not only literary words in the dialogue, but also is expected to interpret the movements or events in every scene in the movie.

However, the movie has its own uniqueness, because it combines the words in the dialogue, in motion pictures, and audio that makes the audiences enjoy the movie. A movie usually presents many themes, but we must be creative in seeing the movies. We should choose which have an education or moral value which is very meaningful to us. The movie is not only entertains but provides lessons that could provide good effect from movie.

\section{Review Literature}

Many people have already been familiar with the word of movie or film. Either those who live in big cities or those who live in remote areas, people can enjoy various movies such as, comedies, action, war, fiction, drama and many others. By watching movies people get relax from their daily activities.

Many of the dramatic forms in the twentieth century, for example, have evolved in interaction with film (movie), whose means of photographic depiction far surpass the means of realistic portrayal in the theater. Drama could therefore abandon its claim to realism and develop other, more or abstract forms of presentation (Mario, 2011: 54).

The most obvious difference between movie and drama is the fact that a movie is recorded and preserved rather than individually staged in the unique manner of theater performance. In spite of their difference forms and media, drama and movie are often categorized under the heading performing arts because they use actors as their major means of expression. What is exactly the definition of movie itself?

According to Monaco in his book "How to read a film" as stated in Nabi Khan, Tusher's site, movie is an art that contains melody, harmony, rhythm and it clarifies how this particular art form is shaped by capitalization (Khan, 2014).

\section{Kinds of Movie}

As people have already known, there are many kinds of movie genres. A genre is a word for a type of movie or a style of movie. Movies can be fictional (made up), or true, or a mix of the two. Dirks wrote in his site, there are some main movie/film genres, as the following (Dirks, 2014).

\section{Action Movie}

It is a movie where action sequences, such as fighting, stunts, car chases or explosions, take precedence over elements like characterization or complex plotting. The action 
typically involves individual efforts on the part of the hero, in contrast with most war films.

\section{Comedy}

Comedies are light-hearted plots consistently and deliberately designed to amuse and provoke laughter (with one-liners, jokes, etc.) by exaggerating the situation, the language, action, relationships and characters.

\section{Horror}

Horror films are designed to frighten and to invoke our hidden worst fears, often in a terrifying, shocking finale, while captivating and entertaining us at the same time in a cathartic experience.

\section{Musical}

Musical/dance films are cinematic forms that emphasize full-scale scores or song and dance routines in a significant way (usually with a musical or dance performance integrated as part of the film narrative), or they are films that are centered on combinations of music, dance, song or choreography.

\section{Science Fiction}

Sci-fi films are often quasi-scientific, visionary and imaginative complete with heroes, aliens, distant planets, impossible quests, improbable settings, fantastic places, great dark and shadowy villains, futuristic technology, unknown and unknowable forces, and extraordinary monsters ('things or creatures from space'), either created by mad scientists or by nuclear havoc.

\section{The Elements of Movie}

As the researcher has mentioned above many dramatic forms in the twentieth century have evolved in interaction with movie, which means of photographic depiction far surpass the means of realistic portrayal in the theater.

Many successful playwrights and movie directors at the time followed the theory of playwriting and drama that was written more than two thousand years ago by Aristotle. In his works, he outlined the six elements of drama in his critical analysis of the classical Greek tragedy Oedipus Rex written by the Greek playwright, Sophocles, in the fifth century B.C. The six elements are: theme, plot, characters, dialogue/language, music, and visual element/spectacle (Manali, 2011).

\section{Theme}

There are some experts' explanations about theme in the story. The theme is the main idea of a work of literature. Often the theme is a message about human nature. Some stories are written purely for entertainment. Their writers do not try to make statements about life or the human condition. Most serious writing, however, is based on the theme, although it is seldom stated directly. Careful reading and thought may be necessary to uncover this theme. 
The theme or central idea of a story corresponds to the meaning of a human experience; it may be anything that could make a memorable experience. It comments upon some aspect of life and has value outside the story.

According to (Peck and Coyle 2007: 88) "theme is the large idea or concept it is dealing with. By theme, people can imagine that it should be expressed in the form of expression as the implication of whole story, but it cannot tell us the separable of the story. By comprehending the theme, people can guest the core of the content. Interesting theme will make people curious to watch the whole story".

\section{Plots}

Peck and Coyle mentioned that "Plot is said to be the fully-developed version of the story." It takes account of the nature of the each other and their dramatic effect.

Plot is also logical combination of different elements of the action in a literary text" (Klarer, 2007: 141).

Based on the material that the researcher has already learned in the class, plot is designed into 5 storylines which includes exposition, rising action and climax, followed by a falling action and resolution.

\section{Exposition}

Dristle and Glick explained in their book entitled "Literature", that exposition is the part of a plot that provides background information and that introduces the setting and the important characters (Dristle, Gail\&Glick, 2007: 677). Another source explains that exposition is the first element of a linear plot when the initial situation of the enfolding action is reveal (Klarer, 2007: 134).

Exposition is the beginning of the story that usually concerned with introducing characters and setting. It begins with an event that affects event $\mathrm{A}$ and $\mathrm{B}$, and ends with resolution of the problem or conflict in a story. The structure of the plot could consist of the beginning, middle and ending.

\section{Rising Action (Conflict)}

A conflict is a struggle between opposing forces. Conflict is one of the most important elements of stories, novels, and plays because it causes the action. There are two kinds of conflict: external and internal. An external conflict is one in which a character struggles against some outside force, such as another person. Another kind of external conflict may occur between a character and some force in nature. An internal conflict takes place within the mind of a character. The character struggles to make a decision, take an Rising Action or conflict is a struggle between opposing forces. This struggle creates tension and suspense and is an essential ingredient in every play or story. A conflict may be either internal or external (Umm, 2007:7). 
Conflict is the central part of a story during which various problems arise, leading up to the climax. Conflict is the "problem" in a story which triggers the action. There are five basic types of conflict:

Person vs. Person: One character in a story has a problem with one or more of the other characters;

Person vs. Society: A character has a conflict or problem with society-the school, the law, tradition;

Person vs. Him or Herself: A character struggles inside and has trouble deciding what to do;

Person vs. Nature: A character has a problem with some element of nature, a snowstorm, avalanche, bitter cold;

Person vs. Fate A character has to battle what seems to be an uncontrolled problem.

\section{Climax}

Climax is the high point of interest or suspense in a story or play. It is the moment when the outcome of the story suddenly becomes clear. The climax comes near the end of a story, with action and suspense building to an emotional peak ( Gail\&Glick, 2007: 678 ).

The climax is the high point of the story. This stage is the point of emotions, the greatest attention and thrilling if the problems encountered can be resolved or not.

\section{Characters}

Based on the researcher opinion, characters are the people, someone (actor/actress), or something act in the story. They play important rule, because characters are essential things to builds up the story.

Kennedy, (2012) stated that a character is presumably a created person who inhabits a story, acts in a reasonable consistent manner, and that the author has provided him with the motivation.

Jones, in his book titled (Outline of Literature) explained that characterization is depicting of clear images of a person. There are two methods of characterization: the dramatic and the analytic. In the dramatic we form our opinions of the characters from what they do and say, from their environment, and from what other characters think of them". In the analytic method the author comments upon the characters, explaining their motives, their appearance, and their thoughts (Kennedy, 2012: 43).

According to DiYanni, (2007: 743) "characters bring plays to life." First and last we become absorbed in the characters: how the look and what their appearance tells us about them; what they say and what their manner of saying expresses; what they do and how their actions reveal who they are and what they represent. We may come to know them and respond to them in ways we come to know and respond to actual people, all the while realizing that characters are literary imitations of human beings.

\section{Dialogue/Language}


A dialogue is a conversation between two or more characters. Such conversation makes the characters in a story seem more real and provides hints about their personalities. Dialogue is used in almost all forms of writing, but it is most important in drama (Jones, 1968: 33).

Language used in drama is deliberately chosen by playwright with the emphasis function for communication. Every playwright has his own style in choosing vocabulary/diction used in drama to express their thoughts and feelings. Besides selection of vocabulary, language is also related to the choice of style.

The selected language chosen by playwright will be used in drama script writing. In general, they choose understandable language. It means that they use communicative language with the diversity of languages used in daily life which is related to the environment, social culture, and education. For the sake of this communicative considerations are not uncommon playwright deliberately ignores the existence of grammar rules. Spoken language itself is chosen to revive the dialogue and the story of drama. While dialogue has four major functions: to reveal character, to advance the plot, to express subtext, and to get a laugh or entertain (Billy, 2014).

\section{Spectacle/Visual Element}

Spectacle or visual element of drama/movie can involve all of the aspects such as the setting (where the story takes a place), its scenery, costumes, props and special effects needed in a drama/movie.

Setting is the time and place of the action of the story. It is indicated to the readers by descriptions of customs, manners, clothing, scenery, weather, geography, buildings, rooms, furnishings, and methods of transportation. Sometimes setting is fairly unimportant. At other times, a detailed description of the setting is needed to create mood in the story (Dristle, Gail\&Glick, 2007: 677).

Abrams states that the overall setting of a narrative or dramatic work is the general locale, historical time, and social circumstances in which its action occurs; the setting of a single episode or scene within such a work is the particular physical location in which it takes place.

\section{Moral}

According to Hurlock (1977:386), the word "moral" comes from Latin word "mores", meaning manners, customs, and folkways. Behavior which may be called true morality not only customs to social standard but also is carried out voluntarily. It comes with the transaction from the external to internal authority and consists of conduct regulated from within. It is accompanied by a feeling of personal responsibility for one's act (Dristle, Gail\&Glick, 2007: 684).

She also explained that moral behavior means behavior in conformity with the moral code of the social group. It is controlled by moral concepts the rules of behavior to which the members of a culture have become accustomed and which determine the expected behavior pattern of all group members (Abrams, 1999: 284). 
Dristle and Glick explain in their book entitled Literature, that moral is the lesson taught by a story. It is meant to be a basic guide line for living. Examples of morals include "Honesty is the best policy" and "Look before you leap" (Hurlock, 1977: 386).

Moral is a human term in defining a human or other person related to their actions that have a positive value. A human who does not have moral is called as immoral. It means he does not have a positive value in other people sight. So, moral is an absolute thing owned by humans. Term of moral related to the socialization process of the individual, without moral people cannot do the process of socialization.

Moral is an act/behavior of someone in his/her interactions with others. If someone's behavior correspond with the values prevailing in the society and their communities can be accepted, then the person is considered to have good moral. Some people say that moral is a product of culture and religion.

\section{The Kinds of Moral}

Barcalow states in his book that moral issues arise more fundamentally when the choices of people face will affect the well-being of others by either increasing or decreasing it, causing them harm or benefit (Dristle, Gail\&Glick, 2007: 680). A good behavior will carry into a good life. Still in the same book, he also explained that there are six kinds of moral theories, those are:

\section{Moral Nihilism}

Moral Nihilism refuses moral objectivism which maintains that nothing is right or wrong since there is no correct or incorrect moral code or system of moral principles. It claims that all moral evaluations are more or less meaningless or senseless. Therefore, it neither believes nor makes any moral evaluations of the behavior of anyone else. It does not have a moral code that because rejects the idea of a moral code. According to Moral Nihilism, nothing is morally right or wrong, good or bad, required or prohibited. The word "nihilism" comes from the Latin word nihil, which means "nothing" (Barcalow, 2006: 4)

\section{Moral Relativism}

Moral Relativism shows that the truth of moral principles can only be true relative to (or true for) some identifiable individual or group. It rejects (deny) that there is only one correct moral code that ties together all societies. Therefore, it maintains that whatever a society believes is right or wrong for that society (Barcalow, 2006: 34).

There are some versions of the moral relativism. Protagorean, Relativism tells us that every society or culture has its own moral code and whatever a society's moral code says is right or wrong for that society. Another modest version of Moral Relativism claims that all societies have equal moral code. There is not society's moral system which is more correct than others although it has contradictory moral beliefs about certain forms of behavior. 


\section{Moral Egoism}

Moral Egoism states that morality never requires people to sacrifice their own selfness interest to help or avoid harming others; it permits people to do whatever is in their own self-interest (Barcalow, 2006: 36).

\section{Moral Absolutism}

Moral Absolutism claims that there is only one correct moral code, many or most of whose moral principles are absolute. An absolute principle does not permit exceptions. It only be plausible if the principles is fairly specific or qualified. That is, a moral principle may be absolute if it is expressed as a conditional statement (an "if-then" statement), such as "In circumstances C, it is wrong to steal (Barcalow, 2006: 38).

\section{Value}

When people watch a movie or read a novel, as a good audience/reader, people will look for the values contained in the movie/ novel they watch/read. If people do not find them, then they can be very sure that what they are reading is not worthy for them. It means that the story does not have values which they want to find out. So, what does the value mean?

Value means the worth of a thing. In a narrower sense to cover only that to which such terms as "good" desirable or "worthwhile" are properly applied and in the wider sense to cover, in addition all kinds of rightness, obligation, virtue, beauty, truth and holiness.

While according to Earle, value is positive quality of anything whereby it is desirable, useful, interesting, good, and important. Only a few of the terms are available for the expression of positive values. Whether values are part of the intrinsic nature of things or simply a matter of how humans respond to things is controversial (William, 1992: 297).

The Kinds of Value

Buzan explained in his book entitled "The Power of Spiritual Intelligence", there are many kinds of moral values, such as (Buzan, 2012: 29)

\section{Responsibility}

Responsibility is being accountable for who you are and what you do. Responsibility is being dependable and trustworthy. Someone who is responsible does his/her best and does not blame others for his/her mistakes. A responsible person makes sure a job is done correctly and on time. A person who is responsible has a moral duty to follow through and complete assigned tasks shows that you are responsibly (Collin, 2012: 29).

\section{Cooperativeness}

Cooperativeness involves the fact of doing something together or working together to achieve the goal. Examples of activities that can be done together are: cooperate to make public facilities and clean up the environment.

\section{Sincerity}


Sincerity shows the feeling of willingness, belief, or behavior that we really thinking or feeling. It can be willingness to appreciate something such as when people give donation to the orphanage, they do not expect anything for return, unless the blessing of God.

\section{Love and Affection}

Love is a strong feeling or deep affection for somebody or something, especially a member of family or friend. Affection is the emotional state of liking or loving somebody or something very much and caring about them.

\section{Diligence}

Diligence is having character of being careful and thorough work or effort. People who are diligent will be very careful and always loyal with what they are doing.

\section{Never give up}

Give up means we stop trying to do something. Never give up means we may not stop doing something, not easily discouraged, optimistic, and confident with what we are doing will get a good result.

\section{Method}

This study is designed to be a descriptive qualitative method. Qualitative research method is used because it does not deal with numbers and statistical computation like those in quantitative research. And this study aims at obsering and describing the moral value on "47 Ronin film". And the object of this study is analyze of Moral Values. The researcher gets the data from film video and some parts from the internet which is used by the researcher in this study. The researcher took the data of the study in the form of dialogues, sentences and paragraphs in the film. The primary source from watching the movie "47 Ronin" and history in internet". The secondary source was related to the information of literary books, theory books, internet, articles and also research report. The secondary sources support the primary source.

As the research is a qualitative research, the main instrument is the researcher himself. $\mathrm{He}$ also uses corpuses to analyze the data and the instruments of the study accordance with descriptive qualitative inquiry in which the researcher himself play role as the instrument. As State that only human instrument is capable play in equalitative inquiry. To conduct the data, the researcher watch the film video.

\section{Findings}

After spend several weeks watching and analyzing the whole film video, finally researcher found which video are contents the moral values same as on the problem of the study. The moral values which had been founded by the researcher in this film are as follows:

\section{A. Moral Value Found On 47 Ronin Film}

After reading some definitions of moral and values from some sources, the researcher has opinion that moral value is the values that deal with good or bad of human behavior 
that are involved with human action in their daily life. When people watch movies they will not only enjoy the story line, but also will find some moral values that the authors conveyed in the film, to be a good lesson in their daily life. As the researcher mentioned above, that " 47 Ronin" is a film that is rich of moral values that can educate the viewer. Some moral values that the researcher found in this movie are as follows:

\section{Love and Affection}

Kai is a very friendly and polite person. He never discriminated other people. He is always friendly and polite to them, even though he gets some discriminated treatment, such as when he was young and met with Lady Mika Asano daughter, but some of Samurai members were not pleasant when Kai was found in Tenggu forest then bring back to Lord Asano castle.

\section{Tolerance and Acceptance}

Some of scenes in this movie teach us how to accept and to show great tolerance to others, such as shown on how Yasuno treated Kai because of his half breed. In other scene, Kai helped Yasuno to catch the beast with head bowl and confess that beast has caught by Yasuno although in the fact he(Yasuno) wasn't catch that beast, but he accept it was Yasuno work.

In other scene, Lord Asano the leader of Ako has succeeded teaching his Samurai member to respect and tolerate then accept each other even though they are different. Since then, Kai had never been mocked and ridiculed again by the samurai member.

\section{Determination}

Chief Samurai Oishi power in arrangement the member insight about him, motivate more Kai determine and dedicate himself as a Samurai.

Though, the way to achieve his dream was not easy, but he still did the job hunting as a Samurai. As seen in the movie, Kai himself has worked very hard to pursue his goal, to be a Samurai. But it is not easy to get it, because some of problem always came to Kai and made him almost gave up and leave the Ako province, but Mika and her father loved which made him staying.

\section{Positive Attitude and Self Control}

Young Kai grew up and became a person with positive attitude and has a good self control. When he went to a forest with the Samurai member, Yasuno, the one of Samurai member who was envious with him in the forest area chased him away and tried to unsheathe a sword upon him, Kai just went away without complaining and arguing.

\section{Honesty}

The whole story of this movie has shown Kai's honesty. Starting when he was child, he told where he is came from about his real condition and how he was found on Tenggu forest. He was a child with half breed who was mocked and ridiculed by his friends. Sometimes he could be angry, sometimes he just accepted his friends' treatment and chief samurai' punishment to him, and even the worse thing was his Samurai friends do to him especially Yasuno. Yasuno did not like Kai because he is stranger man or in the 
other words half breed who is always disturb him in his mind when he was met him(Kai), and he would be angry to Kai as he thought Kai was only disturbing him.

\section{Patience}

Twenty-four times he had been turned down from his training of his dream Samurai member. It was not a short times, he had to prepare himself with hard training, until he run out of time and train, but it had no result. He still kept trying and always reminded that he will be a member of Ako province Samurai even though he was half breed and always enviously by his friends especially Yasuno, such he narrated in this scene. Finally, his patience brought him to be one of 47 Ronin who ever lived and from this history of Japanese Bushido began.

\section{Initiative and Courage}

As he run out time and train, Kai had an initiative to train with his other samurai friends. But Yasuno's attitude has made him dare to state his courage to stay focus in training and his goal to be member of samurai.

\section{Motivation}

After Lord Asano found Kai in Tenggu forest and make Kai same as his son, Kai himself vow that he would repay Lord Asano's love and kindness also Mika's love by serving Ako's province as a Samurai and protect Lord Asano and his daughter Mika.

\section{Self Respects}

Kai is never discouraged because of his half breed. He always motivates and even respects himself of his own achievement, though many people under-estimated him.

Besides those values that the researcher has already mentioned above, there might be some other values contained in the story that she has not found yet, and it will become a challenge for the next researchers.

\section{The Moral Values conveyed in this film}

\section{Love and Affection}

Kai is a very friendly and polite person. He never discriminated other people. He is always friendly and polite to them, even though he gets some discriminated treatment, such as when he was young and met with Lady Mika Asano daughter, but some of Samurai member were not pleasant when Kai was found in Tenggu forest then took back to Lord Asano castle. And also it was showed when he met with Samurai members especially Yasuno who was always envious of him.

Yasuno : You must be Kai. Yasuno, I'm the great Samurai around here.

Hanjo : Hanjo Ryuka, one of Samurai superb in this group. Come on in the front of us, Kai.

Yasuno : We heard you coming all the way from Tenggu forest and you are a half breed. Hanjo : Where You from?

Kai : I came from Tenggu forest when I was young Lord Asano saved me then took me here.

Yasuno : We're gonna look at it in a minute, Kai. Just come on in and tell us why you wanna be a Samurai. 
Kai : Ok, it's a...hope. It's all I ever wanted to be. Ever since I was in forbidden forest I had want to be a Samurai.

Hanjo : You must have had some pretty inspiring Samurai.

Kai : Oh, well. I had an inspiring Samurai chief his name is Oishi. But my master when I in Tenggu forest they were my inspirer too, although them though me to be a murder.

Hanjo : What kind of Master is that?

Kai : One who makes it possible for a kid to learn, even if he is different. In a way that, the best master I ever had was my half breed.

Hanjo : You don't have to talk about...

Kai : No, that's ok. I make a point of being open about it. It's never off the list to other people. They can ask me anything they want about it any time.

Hanjo : Then you must get some pretty interesting questions.

Kai : Oh, yeah. Sometimes it gets really personal.

Yasuno :I hope this question isn't too personal, Kai. Do you make those noises in your sleep?

Kai : I don't know. I'm asleep. (They laugh) No, I don't in my sleep. When I'm relaxed, the noises give me a little bit of a break, like just now.

\section{Tolerance and Acceptance}

Some of scenes in this movie teach us how to accept and to show great tolerance to others, such as shown on how Yasuno treated Kai because of his half breed. In other scene, Kai helped Yasuno to catch the beast with head bowl and confess that beast caught by Yasuno although in the fact he (Yasuno) wasn't catch that beast, but he accept it was Yasuno work.

In other scene, Lord Asano the leader of Ako has succeeded teaching his Samurai member to respect and tolerate then accept each other even though they are different. Since then, Kai had never been mocked and ridiculed again by the samurai member. As in scene below:

Oishi : Today is the first time for us training together in this field, I hoped all of you here could follow the training with great care.

Yasuno :Sir! A moment please, does the half breed train with us?

Oishi :Yes he does. Did you here objection of him here?

Yasuno : But he is different with us and we are here do not agreed that he joint train in this Samurai member.

Oishi : What's that?

Yasuno : It's really do not expected by all of us here because he was different as beginning and do not looked like Samurai.

Oishi : Show me that there was in our Samurai rules that half breed cannot joint as a Samurai members?

Yasuno : Hmhmhm...Yeah it's not rule in the samurai, but we can't training with him.

Oishi : Well, who you are here do not accepting or objecting because of Kai half breed rise your hand?

Oishi :See, no one of you up your hand upon him. It's mean that all of you here can receive him to train with you. 
Yasuno : It's doesn't mean that we are here pleasant about him here.

Oishi : Do not judge someone because he is difference with us, but togetherness is more important thing for all of us here. Come! We started our training soon.

\section{Determination}

Chief Samurai Oishi power in arrangement the member insight about him motivate more Kai determine and dedicate himself as a Samurai.

Though, the way to achieve his dream was not easy, but he still did the job hunting as a Samurai. As seen in the movie, Kai himself has worked very hard to pursue his goal, to be a Samurai. But it is not easy to get it, because some of problem always came to Kai and made him almost gave up and leave the Ako province, but Mika and her father loved which made him staying. It is appear in scene below:

Lord Kira :How dare you wear the armor of a

samurai! You're a half breed!

Kai : I cannot deny it.

(turns to the Shogun)

But my father was an honored

samurai. He fought alongside you

at Sekigahara, Lord Shogun. I only

wanted to display my skills before

you to honor his memory.

Shogun : You have demonstrated great abilities...

Kai :(Kai's fill with pride), it is really great honor to me because

of my majesty encomium.

Shogun : but no matter what you accomplish, a half breed will never be worthy of being a samurai.

Kai : But my majesty, it's not fair if we just judge someone because he was different than other (samurai) honor and courage I though it's more essential.

Shogun : (to his men)

Strip him of his armor and have it

tainted instantly, the Shogun's elite guard come

burned. It is violently ripping the armor off his body

Kai : Kai vow to himself that he must be the great samurai even though he would lost his life, and dedicate whole his life to Ako province especially Lord Asano and his daughter Mika.

\section{Positive Attitude and Self Control}

Young Kai grew up and became a person with positive attitude and has a good self control. When he went to a forest with the Samurai member, Yasuno, the one of Samurai member who was envious with him in the forest area chased him away and tried to unsheathe a sword upon him, Kai just went away without complaining and arguing.

Lord Asano : Stop Yasuno!!! said Lord Asano, what will you do?

Yasuno : My Lord, he is a demon I'll killed him by my sword.

Kai : No, no, I do not a demon beg to you my forgiveness because of my mistaken. 
Lord Asano : Yasuno, did you hear that what he she? He said he doesn't a demon did you forgot what I was ever thought you about human relationshi

Kai : No, I understand. I can't help making these normal same as usual. Because I have half breed. It's a really my weakness and I can't talk about it.

Lord Asano : You go have to leave the forest. I've got to think about the other members.

Member 1 : Hey, Yasuno! Leave the guy alone. He's fine.

Member 2 : Hey, man, we're twosome and our buddies don't appear to be showing. Would you like to join us?

Golf Man : If you don't leave, I'm going have to punish you because of the bad attitude.

Yasuno : Okay... Okay... I'll walk away soon?

\section{Honesty}

The whole story of this movie has shown Kai's honesty. Starting when he was child, he told where he is came from about his real condition and how he was found on Tenggu forest. He was a child with half breed who was mocked and ridiculed by his friends. Sometimes he could be angry, sometimes he just accepted his friends' treatment and chief samurai' punishment to him, and even the worse thing was his Samurai friends do to him especially Yasuno. Yasuno did not like Kai because he is stranger man or in the other words half breed who is always disturb him in his mind when he was met him(Kai), and he would be angry to Kai as he thought Kai was only disturbing him .same as in scene below:

Oishi :Kai, what would you do when Ako province attacked by enemies?

Kai : I'd give all my life and soul to protect Ako especially Lord Asano and his daughter Lady Asano, it's my vow that was I ever had in my life.

Oishi :You going to prove it, don't just used a beautifully words isn't it?

Kai :Yes, my lord I'll prove it to you, I myself as stake if I deny my own vow.

Yasuno: Really? But I doubtfully that will come true, because it's come from your mouth

Kai : I'd to proof it later to all of you here, when Ako province attacked by other province, I will be the first person in front line to defend Ako.

Oishi: Enough both of you, ok Kai I trust your words do not make me regret because of you.

\section{Patience}

Twenty-four times he had been turned down from his training of his dream Samurai member. It was not a short times, he had to prepare himself with hard training, until he run out of time and train, but it had no result, he still kept trying and always reminded that he will be a member of Ako province Samurai even though he was half breed and always enviously by his friends especially Yasuno, such he narrated in this scene. Finally, his patience brought him to be one of 47 Ronin who ever lived and from this history of Japanese Bushido began. As the scene emerge below:

Kai words

So, I decided it wasn't half breed. I just hadn't found the right place yet.

I'd keep barking and I wasn't quitting until I found that chief of samurai. I made a map of every place where I hadn't dream before. If the Samurai chief wasn't here I'll found 
him and force it to face with me, because I really serious be the one of you here(samurai) . I didn't care. I needed himself (chief). I wasn't going stop, until you brought him here to me.

\section{Initiative and Courage}

As he run out time and train, Kai had an initiative to train with his other samurai friends. But Yasuno's attitude has made him dare to state his courage to stay focus in training and his goal to be member of samurai.

Yasuno: I guess you never heard from that samurai chief.

Kai:No, not yet. Chief not back yet but I haven't worried it what's going on you asked me?

Yasuno:Ok it is good. I just said "Ok".

Kai:I know what you mean. You don't think anybody would hire me, if they had a choice.

Yasuno:So you're a mind-reader now?

Kai:You know what, Yasuno? This is going be my best test day here even though I don't know what are the problem.

Yasuno:Why don't you wait and see if you got chief first?

Kai:I'm going to wait him and asked him what actually happening here, Yasuno. I just have to stay focused.

Yasuno : Why can't you stay focused and realistic at the same time? What's wrong with that?

\section{Motivation}

After Lord Asano found Kai in Tenggu forest and make Kai same as his son, Kai himself vow that he would repay Lord Asano's love and kindness also Mika's love by serving to Ako's province as a Samurai and protect Lord Asano and his daughter Mika. In this scene would appear how the great Motivation from Kai to Lord Asano and Ako province as dialogue below:

Lord asan : I believe to all of you here will loyal and obey to my order.

Oishi : Absolutely yes my Lord, we'd give all our life and soul to serve you. Lord Asano: Kai how about you? Would you serve me and the province in the end!!!

Kai:My Lord You had really knew who I am at the first time when I was found by you in Tenggu forest, I'd gave all my life to you and Ako province.

Narrator : After heard Lord Asano question Kai vow to himself that he would serve and loyal to Lord Asano and Ako province especially Mika as who was he loved.

\section{.Self Respects}

Kai is never discouraged himself because of his half breed. He always motivates and even respects himself of his own achievement, though many people under-estimated him. As showed in the scene below:

Yasuno : You the half breed!!! Came closer next to me.

Kai : What I can do for you my friend?

Yasuno : Wow, how pride of you when I called you a half breed don't you ashamed?

Brad : No I don't, I proud of my life and blood why I could shame of that.

Yasuno : looked at after him, how dare he confess without fear and ashamed. 
Kai : Thank you because you calling me a half breed, I'll always remember where I was from and what Am I.

Yasuno: Wow it's really interesting.

Besides those values that the researcher has already mentioned above, there might be some other values contained in the story that she has not found yet, and it will become a challenge for the next researchers.

\section{The messages that be delivered can to the viewers}

As good generation, the youths have to be able to choose information which is good for them, as they have a very important role in filling and continuing the development in their country. Movie is one of the important factors that influence the shaping personality of the youths.

There are some main points in this movie that audience can take as their behavior's guide, such as:

1)Kai as the half breed samurai can though to viewers those differences are not the great matter to gaining the dream in life.

2)The senses of never give up, optimism, and self confidence help the viewers to always be positive minded in their life.

3)The sense of tolerance, perseverance, friendliness, politeness, and responsibility are the keys of success of everyone in chasing his dream.

\section{Conclusion}

However, watching movie that contains moral values is more meaningful and useful to have us get new insights about the values conveyed in it, than those kinds of movie that are full of crime, horror, and jokes that sometimes just waste our attention and time.

So, the last but not least, the researcher only could give conclusion: please, watch movies that could educate its audience's moral and behavior than other movies that only waste the audience's time.

\section{Suggestions}

The researcher would like to give some suggestions related to the movie "47 Ronin" directed by Carl Rinsch that probably useful for everyone who will study or do the research.

\section{To the teachers/lecturers}

After watching and analyzing this movie, the researcher hopes;

a. The teachers/lecturers will not discriminate the students with deficiencies.

b. The teachers/lecturers know how to handle different students with loving and caring.

2. To the students

After watching and analyzing this movie, the researcher hopes;

a. The students can study and absorb some moral values contained in the movie to be applied in their daily life. 
b. The students believe that perseverance, never give up, optimism, self confidence, and hard working are the keys of success in chasing their dream, whatever their condition.

c. The students will never ridicule and always respect each other.

3. To the viewers / readers

a. No matter, the children who grow up with divorced family would face such psychological conflict, which might result in worse situation, such as Kai, who suddenly has difference blood after his parents' got divorce and pass away. Therefore, be loyal to each spouse are the best way to avoid the children having such difficult situations.

b. The audience could grasp the moral values conveyed in the movie "47 Ronin", and even could apply them in their daily life, especially to respect each other (even to the deficiencies persons).

However, watching movie that contains moral values is more meaningful and useful to have us get new insights about the values conveyed in it, than those kinds of movie that are full of crime, horror, and jokes that sometimes just waste our attention and time.

So, the last but not least, the researcher only could give conclusion: please, watch movies that could educate its audience's moral and behavior than other movies that only waste the audience's time.

\section{REFERENCES}

Abrams, M.H. (1999). A Glossary of Literary Terms Seventh Edition. Boston: Heinle \& Heinle.

Barcalow, Emmett. (2006). Moral Philosophy: Theories and Issues. Belmont, CA: Wadsworth Publishing Company.

Buzan, Tony. (2003). The Power of Spiritual Intelligence: 10 Ways to Tap into Your Spiritual Genius. USA: HarperCollins Publishers.

Denzin, N., \& Lincoln, Y. (2011). Handbook of Qualitative Research 4th edition. Thousand Oaks, CA: Sage.

DiYanni, Robert. (2007). Literature: Reading Fiction, Poetry, and Drama. McGrawHill Book Company, Inc.

Dristle, Gail A \& Glick, Luann W. (1990). Literature Grade 8: Green Level. New York: McDougal, Littell \& Company.

Earle, William James. (1992). Introduction to Philosophy. Singapore: Mc Graw-Hill Inc.

Hurlock, Elizabeth B. (1977). Child Development. New York: Mc. Graw-Hill Inc.

Jones, Edward. 1968. Outline of Literature. New York: Monarch Press. 
Kennedy, X.J. (2012). Literature is an Introduction to Fiction, Poetry, and Drama. Toronto: Little Brown \& Co (Canada) Limited.

Klarer, Mario. (1999). An Introduction to Literary Studies, 3rd Edition. USA: Routledge Taylor and Francis Group

Stanton, Robert. (1965). An Introduction to Fiction. USA. University of Washington.

Umm Al-Qura University. n. d. Literary Terms Handbook grade 7. Arab Saudi 